\title{
6. Doing things with toponyms: The pragmatics of placenames in Western Arnhem Land
}

\author{
Murray Garde
}

\section{Introduction}

As proper names, placenames do not, by convention, make their way into dictionaries of most languages, although lexicographers working on Australian languages might wish to disagree with this convention. Indeed Indigenous people themselves have insisted on occasion that placenames should play a significant role in dictionary making (Bowern 2009: 327; Aklif 1999). Relationships to land and place-based spirituality are central to Australian Aboriginal cultures and anyone who has had any exposure to an Australian language can testify to the saturation of placename reference in everyday conversation. The inclusion of placenames in dictionaries can be justified on many levels but a dictionary definition of a placename does not necessarily tell us much about how this special class of proper nouns might be used in everyday interaction in Australian languages. Uttering a placename indexes a particular location, but the reasons speakers might choose to do this are not limited to singling out a geographical site in the minds of their interlocutors. Because of the nature of relationships between placenames and the hierarchical structure of placename organisation in many Australian languages, speakers are always making choices about how to index a location. ${ }^{1}$ Such choices tell us something about speaker intentions and the nature of the commitment a speaker has to the propositions expressed with the use of a particular toponym.

The purpose of this chapter is to explore how speakers of Bininj Gunwok dialects in Western Arnhem Land 'do things' with placenames, such as achieving particular interactional goals. Such interaction is presented so as to reveal something of the conception of toponymy in Western Arnhem Land. Analysing interaction ideally requires illustration with transcripts of natural speech and so this paper is organised around a number of such transcripts. I will look at five contexts of usage commencing with a discussion of place naming in

1 As others have pointed out (Morphy 1984: 26; Keen 1994: 104), it would not be totally accurate to describe Aboriginal land as bounded by a hierarchy of areas with clear cut boundaries. A better description would involve named sites as focal centres that have contextually determined expansions. 
the Bininj Gunwok-speaking world and how the availability of choice widens the scope for pragmatic meaning. Following this, I examine how placenames are mentioned in relation to other placenames, especially in terms of mental maps made manifest by the recitation of placenames along traditional walking routes. Next, I examine the role placenames play as both personal referring expressions and reference to objects. Finally, I describe the practice of using placenames in a particular form of kinship-based joking and other kinds of light-hearted interaction.

\section{The organisation of place naming in Bininj Gunwok}

Bininj Gunwok, a member of the Gunwinyguan family of languages, is a collective name of convenience coined by linguists (e.g. Evans 2003) to designate a chain of dialects best known by the largest variety, Kunwinjku, as spoken at Gunbalanya in Western Arnhem Land. Neighbouring varieties are Gundjeihmi, spoken to the west in Kakadu National Park, Kuninjku, spoken in the Liverpool and Mann Rivers region south of Maningrida and Kune (also sometimes referred to as Mayali), spoken on a number of outstations in the Cadell River district south of Maningrida in central-north Arnhem Land (see imagel).

The structure of Bininj Gunwok placenames is very similar to that described by Merlan (2001) for the neighbouring Gunwinyguan language of Jawoyn. Merlan describes the relationship between Jawoyn placenames and the places they designate as being 'non-arbitrary' (2001: 367), that is, toponyms project a meaning associated with a place, especially the dreaming or totemic identity of a place. Starting from these minimal points of reference, Jawoyn placenames can be 'expanded' (Merlan 2001: 367) to detail their economic, spiritual and cosmological signficance. To use a modern analogy pointed out to me by Peter Danaja, an Indigenous colleague who is a speaker of the Burarra language (coastal north-central Arnhem Land), 'our placenames are like hyperlinks on a computer - clicking on them opens up a story'. Merlan's description for Jawoyn also generally holds true for the semantics of Bininj Gunwok toponyms. Placename meanings extend along a continuum of semantic transparency. At one end of the continuum are maximally transparent forms such as those in (1)-(3): ${ }^{2}$

\footnotetext{
2 Abbreviations: 1- first person, 2- second person, 3- third person, a- augmented (plural), ABL ablative, COM comitative, DEM demonstrative, I- masculine noun class, II- feminine noun class, III- vegetal noun class, IMM immediate, INTERROG interrogative, IV- general noun class, LOC locative, m minimal (singular), NP non-past, ø- zero, P past, place.n.- placename, PP past perfective, prop.n.- proper noun, REDUP reduplication, REL relative, RR reflexive/reciprocal, SEQ sequential, ss.n- subsection name, ua- unit augmented (dual), lengthening is indicated by multiple colons :::.
} 
(1) Nabarrbinj Werrhmeng

na-barrbinj ø-werrhme-ng

I-clan.name 3P-clear.ground-PP

The man of Barrbinj patriclan cleared the ground (of vegetation).

(2)

\title{
Kunj Kadjowkke
}

kunj ka-djowkke

kangaroo 3NP-cross.overNP

Kangaroo crosses over.

(3)

\author{
Kabanibirliyingarrnghmang \\ Kabani-birli-yi-ngarrnghma-ng \\ 3ua-fire-com-negotiate.landscape-NP \\ They (2) walked through the pass (whilst) holding fire.
}

The totally opaque end of the continuum is illustrated by the synchronically unanalysable examples in (4) and (5), although the placename Rarrekbaldeng (4) contains the formative verb theme-deng, which is a marker of a particular class of verbs in Bininj Gunwok. Following the common bipartite structure of many Bininj Gunwok placenames, this suggests a nominal subject rarrek and the verbal predicate baldeng, however these lexemes are unknown in modern Bininj Gunwok.

(4) Rarrekbaldeng

?

Place on the banks of the Mann River, near Kamarrkawarn outstation in the Kodwalewale estate.

(5) Dendenday

?

Place in the Kodwalewale estate.

Many other placenames have familiar or typical Bininj Gunwok morphology even though the semantics of at least some elements are impenetrable, as in (6).

(6)

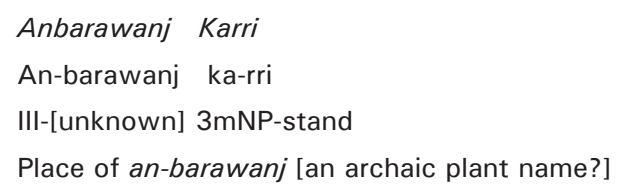

The placename in (6) is an example of the common formula consisting of $X \mathrm{ka}-\mathrm{rri}$ 'X it-stands' (or another stative verb such -ni 'sits' or -yo 'lies'). The morphology of the first segment of the binomial suggests a plant name, as the vast majority of plant names in Bininj Gunwok have a vegetal class prefix (m)an-. The meaning 
of the name an-barawanj is unknown and it assumed to be archaic. An absence of semantic transparency does not mean however, that there is no concomitant 'hyperlink' to an implicit cultural significance of such places.

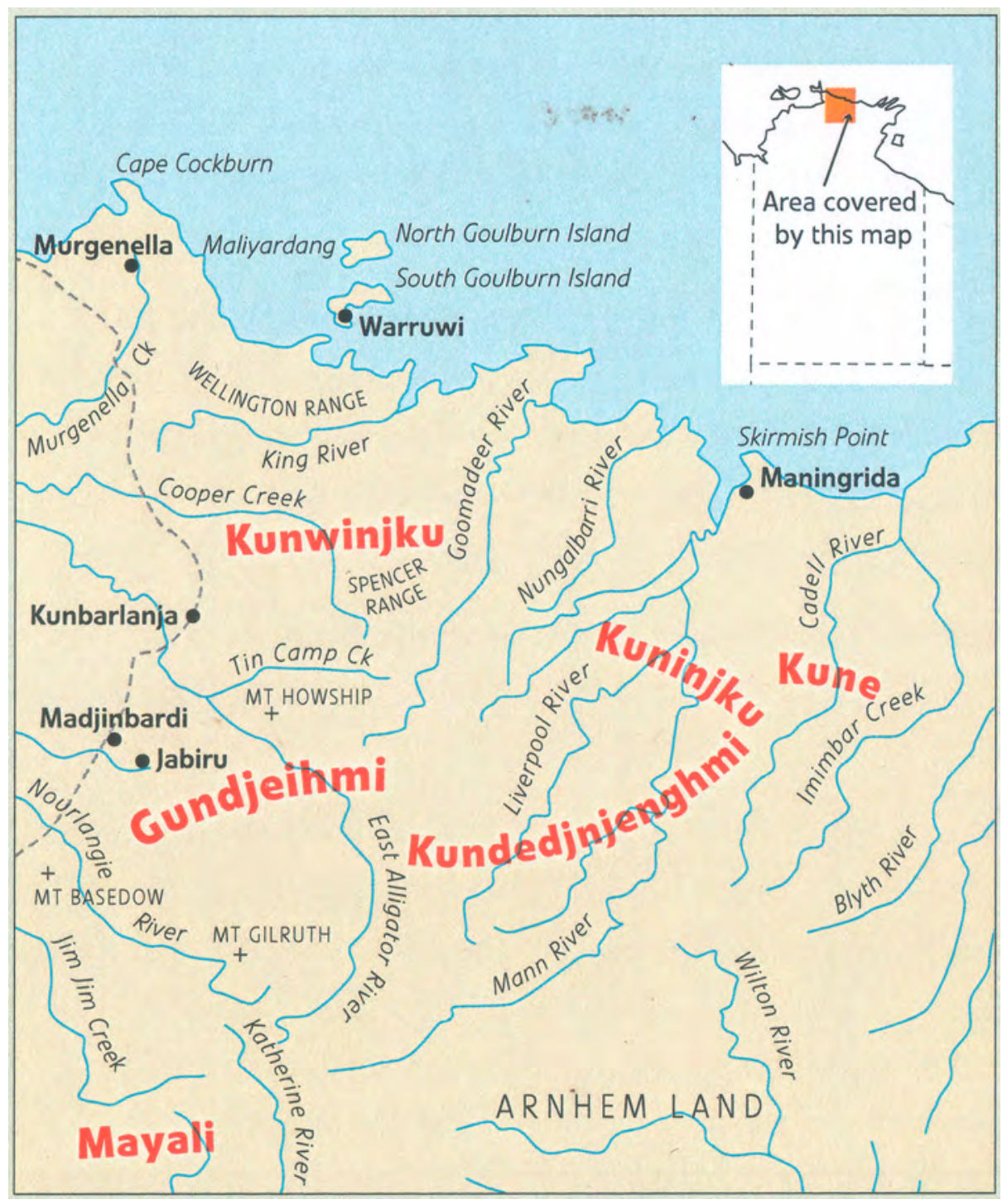

Map 1: Locations of Bininj Gunwok dialects in western Arnhem Land.

Source: Murray Garde. 
On the other hand, Bininj Gunwok speakers do not always acknowledge links between placename meanings and an encoded cultural significance. Land, country and individual sites in certain general contexts are all referred to as kun-bolk in Bininj Gunwok where kun- is a general noun class prefix which includes words in the semantic domains of land, language, body parts and various abstract nouns. A more restrictive term kun-red, refers to any named location which is considered to be a site in a traditional repertoire of those places along walking routes or Bininj man-bolh 'Aboriginal roads'. Kun-red also refers to the concept of 'home, hearth - a place where people live'. When people 'shift camp' carrying all their possessions, they are said to be going reddorrengh, 'camp/home-with', as opposed to just a day trip. Enquiries about the cultural significance of a placename, especially those which tend towards the transparent end of the semantic continuum, are sometimes met with a response along the lines of 'it's just a placename' or 'it's just a kun-red (traditional camping place)'. The transcript in (8) is an illustration of this when I once questioned the knowledgeable Kundedjnjenghmi elder Lofty Bardayal Nadjamerrek about the meaning of a placename Dedjbang which means Vitex acuminata, a tree with edible purple-black fruit:

(8) MG: Yi-bengkan Dedjbang, makka an-me an-dedjbang?

You know that place Dedjbang, is that [related to] the fruit tree Vitex acuminata?

LBN: Kun-red!

It's [just] a placename!

\section{3. 'Big' and 'small' placenames}

In (4) and (5) where there is no translation possible for such placenames, I have instead provided a lexical definition in relation to other placenames. In these examples the translation includes the term 'estate' which reflects the fact that certain placenames index areas that extend further from geographical focal points than others. Such regional placenames are called kun-bolkngeybadjan or kun-bolkngeykimuk, both meaning 'big placenames'. The opposite, kunbolkngeyyahwurd 'small placenames' are lower order named sites within estates. Such 'big name' versus 'small name' distinctions and variations of these categories are found in other Australian languages (Keen 1994: 104; Bowern 2009). The choice of the English term 'estate' is intended to convey something about Bininj Gunwok land tenure, as all estates are owned by a particular kunmokurrkurr 'patrifilial clan' or a 'company' of clans. All kun-mokurrkurr will 
have at least one kun-bolkngeykimuk estate name. Some clans are organised by separate lineages who share the same clan name but each lineage has their own exclusive kun-bolkngeykimuk.

This place-naming structure becomes relevant to pragmatic meaning when speakers make choices about how specific they wish to be, or for example when a speaker wishes to demonstrate their fine-grained knowledge of places by referring to a lesser known or rarely used kun-bolkngeyyahwurd 'small placename'. Choice of placename is also important when referring to the small remote outstation communities or 'homeland centres' which surround regional towns and settlements. In Western Arnhem Land, many outstations are referred to by their kun-bolkngeykimuk or 'big placenames' as such names are more widely known than the local 'small names'. Residents at these outstations in some cases will make use of a variety of designations for an outstation depending on who they are addressing. In-group usage (e.g. outstation residents) is more likely to be restricted to a small placename. In some cases some 'small names' are 'smaller' than others. An example is the outstation of Milmilngkan south of Maningrida which is owned by Kuninjku speaking people of the Kurulk kun-mokurrkurr or patriclan. The name Milmilngkan is not a Kurulk kun-bolkngeykimuk 'big/ estate name'. Residents say that the outstation is actually located on a smaller site called Bulngandi and this is the name they use to refer to their outstation when addressing each other or residents from nearby outstations whom they consider close kin. In official contexts or interaction with out-groups (e.g. in contexts involving interaction with the local outstation resource centre), the outstation is always referred to as Milmilngkan. The Kurulk clan's estate name Kidbulmaniyimarra is rarely used and little known by others outside of the region.

Another large and well-established Kuninjku outstation south of Maningrida is Marrkolidjban. This outstation was established in the early 1970s and is located at a place referred to by the 'small name' of Manbodjub Kayo (literally 'Triodia spinifex, it lies'). Whilst this seems to be common knowledge held by residents and neighbours, the outstation is never referred to by this small name and only ever as 'Marrkolidjban'. The community was established as an official outstation serviced by the government welfare settlement of Maningrida. However, the influential Kardbam clansman Peter Marralwanga is credited with establishing the outstation at a time when his own Kardbam patriclan was politically strong and numerous, and the land-owning Born patriclan was small and lacking in cohesion. ${ }^{3}$ The Arnhem Land patrimoiety system dividing the world into either duwa or yirridjdja moieties also applies to land. Anbodjub Kayo is on Born clan land which is associated with the duwa moiety. Peter Marralwanga and his Kardbam clan were the opposite yirridjdja moiety. The politically incorrect arrangement involving a non-land owning group of the opposite

3 Peter Cooke, pers. comm. 
moiety establishing and occupying a new outstation on someone else's country was also aided by the manipulation of placename conventions. It is common knowledge that the place designated by the name Marrkolidjban is actually an area of important wetland food resources located five kilometres to the east of the outstation at Manbodjub Kayo, and is on land belonging to the Marrirn clan, a neighbouring yirridjdja moiety clan. In 1999 when conducting cultural site surveys in the region, two senior long term residents of nearby Kumarrirnbang and Kurrukkurrh outstations, Peter Nabarlambarl (PN) and Timothy Nadjowh (TN) made the comments in (8): ${ }^{4}$

(8) PN: Anbodjub Kayo, station there, Kunrak Kani, i gat Marrirn, Biliyedj.

Anbodjub Kayo is [the name of] that outstation there [i.e. 'Marrkolidjban']. Kunrak Kani [an important sacred site about 200 metres from the outstation] belongs to the Marrirn clan, [where] Biliyedj [lives] [Biliyedj is a nickname of a senior long term resident at Marrkolidjban who is the eldest son of Peter Marralwanga].

TN: That one Manbodjub Kayo ka-bolkngeyyo.

The name of that place is Manbodjub Kayo.

PN: Im not Marrkolidjban, that big plain you bin look there? That Marrkolidjban. Your brother ka-ni, well Anbodjub Kayo.

That is not [really] Marrkolidjban; have you seen that big plain there [wetlands to the east]? That's Marrkolidjban. But where your brother lives, well that's Anbodjub Kayo.

A similar situation exists for the names used to refer to other outstations nearby. One of the kun-bolkngeykimuk or 'big names' for the Marrirn clan (bordering Marrkolidjban) is Kumarrirnbang (literally $k u$ - locative prefix, marrirn 'proper name of a clan', -bang 'dangerous, sacred, restricted'). This is also the name used to refer to another large well-established outstation which similarly has a kunbolkngeyyahwurd 'small placename' that is no longer used to refer to the location of the outstation. However, in contexts where precision is required (again, cultural site surveys to establish land ownership and clan affiliation registers), the 'small names' become relevant. The transcript in (9) details a discussion between myself and a senior placename expert Jimmy Kalarriya, which took place after a helicopter survey to record named sites near Kumarrinbang outstation.

MG: Kodjok, Kundjurrkamik karrimhdi?

Kodjok [JK's subsection name], so we set out from Kundjurrkamik today?

4 These comments are a mixture of Kriol and Kunwinjku languages. Further, PN speaks a plateau dialect called Kundedjnjenghmi. In this variety, the vegetal noun class prefix which is man-in Kunwinjku, drops the initial nasal to become an-, thus accounting for the variation - Manbodjub Kayo (TN's version) and Anbodjub Kayo (PN's version). 
Indigenous and Minority Placenames

JK: Kukabo, dja karrkad Kuyahyay kure station.

That's on the creek, but up higher on the bank is Kuyahyay, at the outstation.

\section{MG: Kure Kumarrirnbang Outstation?}

Is that at Kumarrirnbang outstation?

JK: Yo.

Yes.

MG: Kuyahyay?

[intonation suggesting - 'I don't know this place']

JK: Kuyahyay. Kumarrirnbang ngarri-bolkngeybuni ku-bolkbadjan.

We used the name 'Kumarrirnbang', the big estate name [to refer to the outstation at Kuyahyay].

MG: Ku-bolkyaw?

(So that is) a little place?

JK: Ku-bolkyaw kure station ka-djaldi. Ku-kabo Kundjurrkamik kaddum Mandjabu Kalurlhdi. Kaddum anekke kaddum ngamed Dulkbordobom manekke manu yikurrmehkurrmeng djurra.

The small name for the outstation still exists. On the creek [from the outstation] Kundjurrkamik is upstream and then Mandjabu Kalurlhdi [literally 'conical fish trap is swollen']. Upstream from there is Dulkbordobom, names which you recorded in your book.

Using a 'big placename' to refer to an outstation can in some contexts create confusion when such big names have also become designations for other focal sites in the 'estate'. An example of this involves the kun-bolkngeykimuk or 'big placename' of Kubumi, which was used to refer to an outstation on the Mann River established in the early 1980s by people of the Kulmarru clan. The kun-bolkngeyyahwurd or 'small placename' for the location of the outstation is Yikarrakkal. The focal place for Kubumi is a stretch of the Mann River where the river widens and white sandy banks are a popular camping place for people from the outstation, which is located only a kilometre upstream to the south. In the period of 1990 to 1997 when I lived at Yikarrakkal, movement between the outstation and the river camp was constant. With both the outstation and the river camp both being referred to by the name Kubumi, it became very difficult to disambiguate reference to these two places when speaking to people who did not live at Yikarrakkal. In 1990 the community decided to deal with this confusion by using the kun-bolkngeyyahwurd of Yikarrakkal for the outstation and the kun-bolkngeykimuk Kubumi, for the river camp. Kuninjku people in the 
Mann River region will refer to the outstation as either Yikarrakkal or Kubumi depending on their assessment of shared knowledge with interlocutors. 'Big names' are more widely known outside of the local sphere of interaction.

\section{Names for djang 'totemic sites'}

Bininj Gunwok placenames do not index landscape features as is the case in English, e.g. Rose Hill, Alice Springs, Rabbit Flat. An exception, at least for an intangible cultural landscape feature, are names for totemic centres, most commonly translated in English as 'sacred sites'. Toponyms are said to be either the name of kun-red 'camping places/traditionally known sites', kunbolkngeykimuk 'big placenames' or djang 'sacred sites/totemic sites'. Placenames that express something of a spiritual totemic force or 'dreaming' which is thought to inhere in a particular place are usually semantically quite explicit (as they are in Jawoyn, see Merlan 2001). Certain, but not all placenames associated with djang 'sacred sites/dreaming' are binomial of the form ' $X$ Djang' or ' $X$ Kadjang(di) (it-djang-stands)' where $X$ refers to the totemic entity associated with the location:

\section{Bidjurru Djang \\ Dird Djang \\ Wayarra Djang \\ Kodjdjorn Kadjangdi}

\author{
'Whirlwind Dreaming' \\ 'Moon Dreaming' \\ 'Ghost Dreaming' \\ 'Woodworm Dreaming'
}

Certain placenames can be referred to either by a placename, or the name of the djang which inheres in the site. On the upper Liverpool River is the outstation Kabulwarnamyo which has the literal sense expanded in (14):

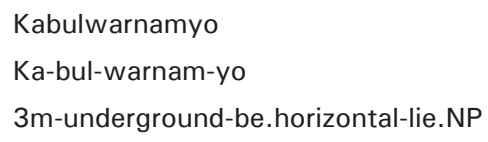

Kabulwarnamyo is a site within the Ankung Djang 'Honey Dreaming' estate. A complex of sites related to honey totems are all located within this estate belonging to the Mok clan. Large underground 'dreaming' honey hives are said to lie under the ground at key sites throughout the estate, as the name Kabulwarnamyo implies. Also located at Kabulwarnamyo is a djang for a species of wasp that preys on the larvae of native honey bees and known in some dialects of Bininj Gunwok as norne. The wasp is held in high regard by Aboriginal people as it is said to lead humans to hives where it will be rewarded with access to the bee larvae once the hive is broken open. The focus of the norne djang at Kabulwarnamyo is a particular Syzygium suborbiculare tree which, during species increase rituals, is struck with an axe in order to increase the abundance 
of both the wasps and honey. Since the establishment of Kabulwarnamyo outstation in 2002, most non-residents refer to the place by the name of the wasp totem Norne, whilst most residents use the placename Kabulwarnamyo. These preferences may be related to the relative ease of pronunciation (two syllables versus five) but there are also contexts where pragmatic meaning is relevant, as when some speakers who are in-group residents use the name Kabulwarnamyo with other residents, but use the name Norne with out-group or non-residents. Such evaluations of the mental states and knowledge of others are in this case influential in determining placename usage in interaction.

\section{Connections of places to other places}

Western Arnhem Land is, like the rest of Aboriginal Australia covered in a network of traditional walking routes which are still known by older Bininj ('Aboriginal people'), effectively in the form of mental maps (Hercus et al. 2002). As already mentioned, these routes are known as Bininj man-bolh 'Aboriginal roads' which are recalled by reciting placenames along a particular route. Not only do mental maps assist in navigation through what can be extremely confusing and dangerous physical environments, they also, as Levinson and Burenhult observe, allow speakers "to linguistically "zoom in" and "zoom out" - to vary the granularity of place description' (2008: 139). Such 'zooming in' becomes extremely important when navigating throughout the dense stone country of the Arnhem Land plateau (see Image 1). A basic way to recite placenames is to list them in the order they are encountered, as in the following text by the Kundedjnjenghmi elder Jimmy Kalarriya. The text in (15) was made as part of a plan to conduct a low altitude helicopter route over the Kunburray estate (or 'big name') as part of a mapping exercise on the Liverpool River.

(15) JK: ...karri-durndeng kurih karri-djalyimiwon nane dubbeno:: Bibiddoy, Kudjarridjbolh, Bundjurrulk, Ngalkodjok Wokyirranj, Ngarrekorulk, Kunjberrinjbuk Wubarr, Kunjberrinjbuk Wubarr ka-yo kumekke, yiman mak Menedji kah-yo Mimburrng manu Wurrkeyele. And same way mak konda na-Durlmangkarr ka-yo. Ubarr.

...we'll go back this way, we'll do it like this through the dense stone country that goes on and on: Bibiddoy, Kudjarridjbolh, Bundjurrulk, Ngalkodjok Wokyirranj, Ngarrekorulk, Kunjberrinjbuk, [which is] a Wubarr ceremony place, at Kunjberrinjbuk there is a Wubarr ceremony ground, in the same way that at Menedji in the Mimburrng region of the Wurrkeyele estate there is also a Wubarr ceremony ground. Well it's the same for this place here for the Durlmangkarr clan. An Ubarr ceremony.

In (15) Kalarriya recites the placenames along this route, until he arrives at a salient feature at the site Kunjberrinjbuk - an Ubarr ceremony ground (see Garde 2011). Here he 'zooms out' to compare the significance of this place with that in another location, a site Menedji (a 'small placename') within a larger region Mimburrng which in turn is located within the kun-bolkngeykimuk or 'big placename/estate' of Wurrkeyele. 


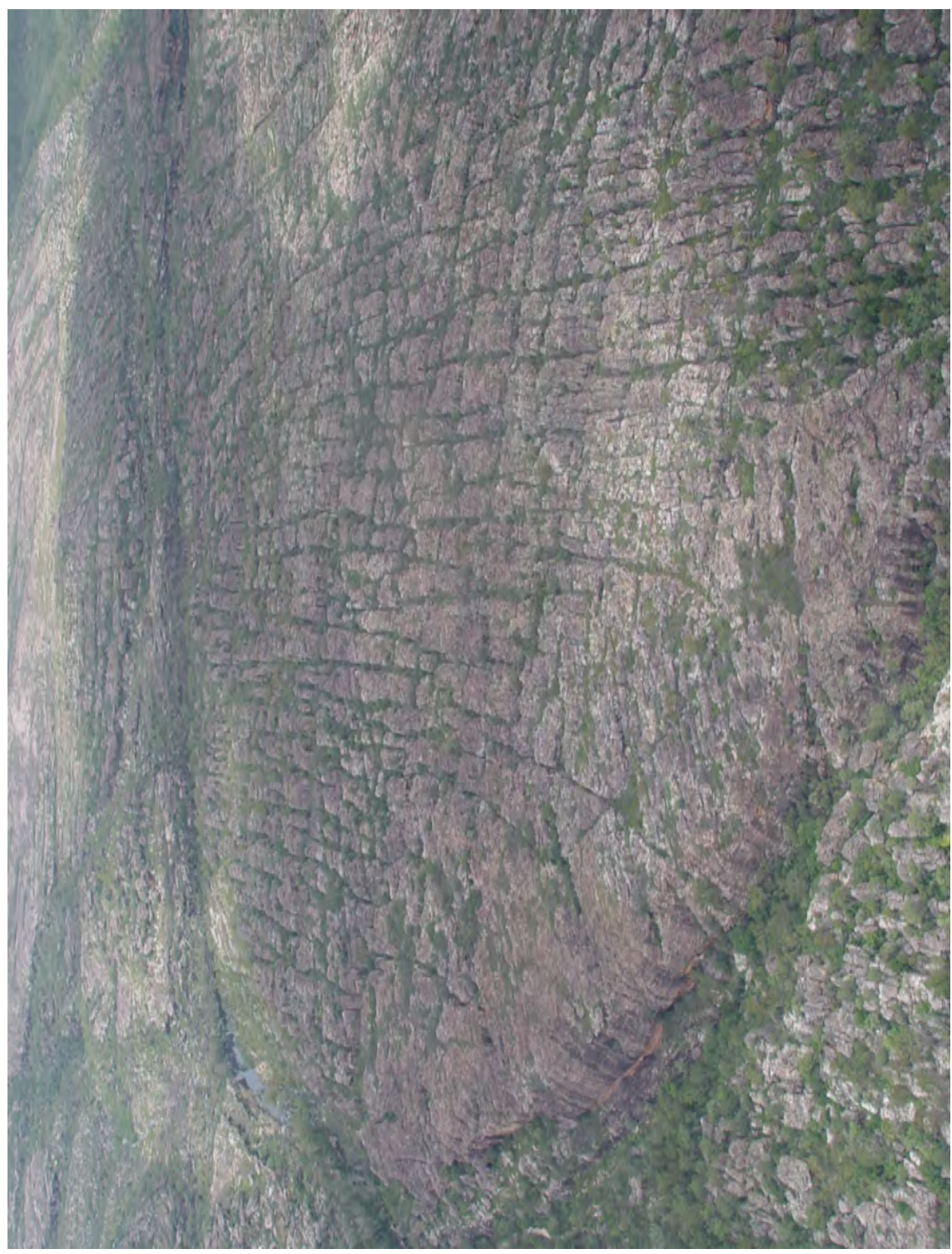

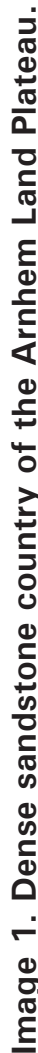

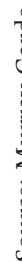


Another common strategy when reciting the places along a walking route is to use tail-head linkage of the form 'arrive at A, from $\mathrm{A}$ to $\mathrm{B}$, from $\mathrm{B}$ to $\mathrm{C}$, from $\mathrm{C}$ to D etc'. The example in (16) is again Jimmy Kalarriya reciting placenames along a river gorge as he explained to younger family members how to walk from places in the Kumarrirnbang estate to those in the Kunburray estate on the Liverpool River in the northern section of the Arnhem Land Plateau. This procedural discourse was produced in a didactic context - a cultural site survey, which apart from the mapping objective, was also organised as an excursion to facilitate intergenerational transfer of knowledge.

$$
\begin{array}{ll}
\text { 1. } & \text { JK: Ngalengman kabarrarnre..., Kamanemdi, Kamanemdi } \\
\text { 2. } & \text { Yolngbuyken, Yolngbuyken Nadjabbarr, Nadjabbarr, } \\
\text { 3. } & \text { Kurrbbirnbaleng, Kurrbbirnbaleng kanjdjikanjdji ngalengman } \\
\text { 4. } & \text { Barrmo Kunburray kabalbarrarnbebme. Mani anbarrarn. mani } \\
\text { 5. } & \text { ngalengman anbarrarn mani yina kabale Kuwuluburrk mahni } \\
\text { 6. } & \text { karrbarda ... konda karrbarda mani anwandjad kabale } \\
\text { 7. } & \text { kabalbarrarnbebme Dobdobma Wurdib nuye kunu kantri... }
\end{array}
$$

This gorge continues on and on... to Kamanemdi, Kamanemdi Yolngbuyken, Yolngbuyken Nadjabbarr, Nadjabbarr Kurrbbirnbaleng, Kurrbbirnbaleng downstream all the way to Barrmo where the gorge comes out in the Kunburray estate. This other gorge here [points], look here, it goes to Kuwuluburrk and the long yams here, yams on this little tributary here which continues, the gorge continues and arrives at Dobdobma there in Wurdib's [a man's name] country.

The clause chaining of the placenames in (16) consist of links in the 'chain' as discrete intonational units - 'from $\mathrm{A}$ to $\mathrm{B}^{\prime}>$ 'from $\mathrm{B}$ to $\mathrm{C}^{\prime}$ suggesting the procedural and linear nature of movement along a route. Further, the headtail chaining reflects the process of arriving and then departing from a site as movement procedes along the walking route. Such tail-head chaining, typical of procedural texts (de Vries 2005), facilitates recall of each placename 'link' along points of this particular mental map. These kinds of recitations of spatial knowledge in Bininj Gunwok discourse are typically organised according to episodes characterised by a particular descriptive resolution. Descriptions of the route are laid out by reciting the order of kun-bolkngeyyahwurd 'small placename' in route segments. The speaker then typically zooms in to a single site to provide more fine-grained cultural, ecological or physiographic detail, as in the reference to the ceremonial associations of the sites Kunjberrinjbuk and Menedji in (15). In (16) Kalarriya 'zooms in' with comments on important resources at certain sites along the route. At Kuwuluburrk (line 5) yams are found and their association with mani anwanjdjad 'this creek/tributary' (line 6) which forms part of a watercourse valley or small gorge that is part of another route. Sets of 'small placenames' are ordered according to their estate and clan affiliations. The recitation in (16) involves listing places along a route in the Kunburray estate, a 'big name' or 'estate' owned by the Durlmangkarr clan. 
Crossing over into the neighbouring estate is indicated by naming the first kun-bolkngeyyahwurd 'small placename' encountered (Dobdobma), and the personal name of the senior traditional owner (line 7). As well as establishing the social context of places, mentioning the name of the senior owner is another way of indexing the 'big placename', without actually mentioning it. Knowledge of this particular estate name - Kunukdi - is common ground to those present. This change in descriptive resolution illustrates the way fine-grained descriptions are then contextualised by 'zooming out' to a regional perspective.

Another type of site recitation along Bininj man-bolh 'Aboriginal roads' involves linear movement in relation to a landscape vector. Such recitation represents the relationship of placenames to landscape form. In the rock country and freshwater drainage systems of Western Arnhem Land, movement by humans in landscapes is indicated with spatial terms that involve travel by foot, either up or down in a drainage system. In (17) Bardayal Nadjamerrek preposes each placename along a water course with the locative adverb kanjdji 'down, downstream'.

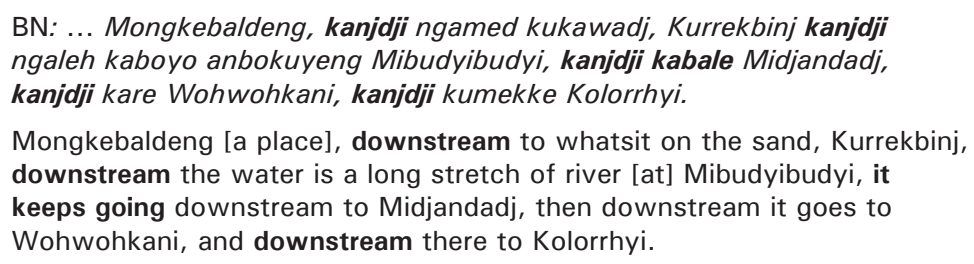

This type of recitation links each site to the next, but the relationships of one place to another are also linked to landscape. Frequent movement by foot along a route and the salient landscape features that distinguish one place from another (as in (17) - 'sandy place', 'long stretch of water') will have played their part in the development of the high linear density of placenames typical in parts of Western Arnhem Land. Obviously the choice of directional adverb in placename recitation, such as that in (17) and (18), is relative to the direction of movement along the watercourse - upstream or downstream.

\section{JK: Andjerd kaddum-djam, kaddum Nawakka, kayawal mankuken, yam.}

Upstream [from Mokkorri] is Andjerd and up further is Nawakka, there are lots of long yams there.

\section{JK: Karrbarda Nawakka, bolk Wurrbbarn, kaddum kadjale Bamkorddji.}

Yams are at Nawakka, belonging to the Wurrbbarn clan and upstream it keeps going to Bamkorddji.

Returning to more immediate pragmatic meaning, the placename recitations in (16)-(18) were produced in didactic contexts, either for cultural site surveys or during an annual bush walk activity organised by Warddeken Ltd, an Indigenous land management company that administers an Indigenous Protected Area on 
the Arnhem Land Plateau. These 10-day excursions involve intergenerational knowledge transfer about places and Bininj man-bolh 'Aboriginal roads'. Elders such as Bardayal Nadjamerrek (deceased 2009) and Jimmy Kalarriya (deceased 2012) used placename recitation in these contexts to demonstrate their knowledge of placenames, walking routes and the resources associated with these places.

\section{Placenames, personal names and other objects}

As land, placenames and identity are so tightly interconnected in Aboriginal Australia, it is no surprise that there are possibilities for the development of metonymic reference, whereby both placenames and personal names are 'signs' (after Pierce 1955), which can in certain contexts refer to each other as 'objects'. That is, a person (or an object associated with them) can be referred to by a place linked to them in some way, either through clan identity or via primary residence. Alternatively, there are also examples of places being indexed by reference to their 'owners' as in (12), line 7. This kind of semiotic relationship between sign and object can be considered both 'indexical' and 'symbolic' in that for the former, there are contextual contiguities between a person and the place where they live, and for the latter, there are cultural conventions that imbue cosmological contiguities between people of a particular social category and places also classed within the same category. ${ }^{5}$

To illustrate the practice of placenames as personal referring expressions, the text in (19) is a conversation between myself (MG) and a visitor to my residence (AB) who had arrived to inform me of the death of a classificatory sibling. ${ }^{6}$
1.
$\mathrm{AB}$ : Yi-bekka-ng?
$2 \mathrm{~m}$-hear-PP
Have you heard?
2. MG: Na-wu njale?
I-REL INTERROG
About what?

\footnotetext{
5 See also Enfield (2009) for a discussion of the relationships amongst signs, objects and interpretants in the Piercean schema.

6 Whilst critics might point out that this type of discourse illustrates how speakers of Bininj Gunwok use placenames when interacting with linguists/anthropologists, it is also worth pointing out that opportunities for recording such 'naturally occurring interaction' (i.e. death announcements) between native speakers are almost nil, and would pose serious ethical challenges. This transcript was constructed from field notes immediately after the event, not from an audio recording, for obvious reasons. Nevertheless, the identity and role of the participants in this particular speech event do not invalidate the point that placenames can also be used as substitutes for personal names in other contexts involving interaction between native speakers.
} 
3. AB: Bolk-warre-minj ngune-danginj, Bulanj.

place-[become]bad-PP 2ua-siblings ss.n.

Something bad has happened [i.e. a death], your brother, Bulanj.

4. MG: Na-ngale?

I-INTERROG

Who?

5. AB: Mankorlod

place.n.

Mankorlod [a place].

Reference to recently deceased people by personal name is tabooed in Australian Aboriginal cultures and there are a number of strategies used to avoid this (see also Garde 2008a). The initial strategies used by speaker AB in (19), line 3 (a kin term and subsection) failed to establish the identity of the deceased person in my mind. After all, the subsection name Bulanj statistically represents one eighth of the male population and this death was totally unexpected. $\mathrm{AB}$ narrows the field of possible candidates in line 5 by using a placename, Mankorlod - both an estate name or kun-bolkngeykimuk and the name of an outstation community of some 12 residents (at that time), although the name could equally have referred to any male persons of Bulanj subsection who are members of the clan associated with the place Mankorlod.

Other cultural motivations for circumspect reference to people can also result in the use of placenames as personal referring expressions. As for the recently deceased, there is also a taboo on personal reference to certain categories of close affines as well as cross-sex siblings. Placenames can at times also operate as substitute referring expressions for people in such contexts. However, the close connection between places and the people who are associated with them can also mean that the use of placenames as personal referring expressions are subject to the same taboos. The conversation transcribed in (20), conducted in 1996, illustrates the co-presence of reference to both places and people who own them, as is also the case in (16). The speaker Bardayal Nadjamerrek was in a conversation with various family members and the rock art researcher George Chaloupka (thus the code switching between Bininj Gunwok and Kriol). The discussion focused on sites on the upper Liverpool River, especially religious sites associated with honey and bees. This particular segment of talk concerns Bardayal's Mok clan and the Ankung Djang 'Honey Dreaming' estate, as well as the land of their close neighbours, the Berdberd clan. In (20), line 2 (which is in Kriol), Bardayal initiates reference to a particular woman of the Berdberd clan. As this person happens to be a classificatory sister, uttering her name is subject to the cross-sex sibling 
name taboo and so she is introduced in terms of her kinship to another person ('Nabarade's mother', (20), line 2). A further complication is that the woman was named after her place of birth, Ngaldaddubbe, a site in Bardayal's Mok estate on the neighbouring Berdberd estate border. ${ }^{7}$ The name Ngaldaddubbe literally means 'she with severed leg(s)' - ngal 'feminine noun class prefix' dad 'leg' dubbe 'terminates/blocked'. An 'expansion' of this placename involves reference to the local honey spirit being Wakkewakken who is depicted in artwork as a woman with no legs. The place is considered a djang 'totemic site' associated with an-yalk 'honey hives found in rock'. As Bardayal's intention is to discuss totemic honey sites such as this, he is faced with a dilemna of cultural protocol.

(20) 1. BN: Konda-beh Kulnguki kaddum kunukka

LOC-ABL prop.n. on.top IV.DEM

On this side is [the place] Kulnguki, upstream there.

2. BN: [Kriol] You know that im mummy Nabarade, im got name there...

Do you know Nabarade's mother, she has a name from that place [which]...

3. BN: no matter, I call im might be Warnkulembakmeng

even though I shouldn't, perhaps I'Il refer to her [by a placename]

Warnkulembakmeng.

4. GC: Aha.

5. BN: im mummy; but my sister, ngal-Berdberd

II-clan.n.

She is [Nabarade's] mother, but my sister of the Berdberd clan.

6. barlmarded ngadburrung Berdberd.

sorry.for.swearing [my]sibling clan.n.

I shouldn't mention her, excuse me, my Berdberd clan sibling.

7. BN: That, im ngal-Berdberd-ni, that Barade im mummy

$$
\text { II-clan.n.-STAT prop.n. }
$$

She was of Berdberd clan, and was Barade's mother,

8. $\mathrm{BN}$ : yi-bengka-n that im maitbi imin born

2-know-NP [Kriol...]

7 People in Western Arnhem Land are often named after their place of birth. For men, a place of birth is referred to as ka-borndokdi 'the spear thrower stands there' whilst for women the equivalent term is ka-djadjdi 'the digging stick stands there'. 
you know, she was I think born

9. BN: that girl long time Warnkulembakmeng

$$
\text { prop.n. }
$$

that girl, a long time ago, Warnkulembakmeng.

10. BN: Nga-yawoyh-durnde-ng nga-yawoyh-durnde-ng

$$
\text { 1-again-return-NP 1-again-return-NP }
$$

"I'Il go back again, I'Il go back again [to that place]"

11. BN: ø-yime-ng Ngal-dad-dubbe.

$$
\text { 3P-say-PP II-leg-cut.off }
$$

she said, Ngaldaddubbe.

12. BN: Kaluk bolk-balmarded, ba-rrang-inj, SEQ place-sorry.for.swearing 3P-stand-PP

At that place whose name I can't say, she was born there,

13. BN: ngadburrung, ...ngadburrung Berdberd.

$$
\text { sibling sibling clan.n. }
$$

my sibling, my sibling from the Berdberd clan

14. BN: nga-djal-kordidj-kordidjme-rr-en

1-just-REDUP-swear-RR-NP

I am swearing at myself

15. BN: tharran my sister

$$
\text { DEM[Kriol] " }
$$

that woman is my sister

16. $\mathrm{BN}$ : imin born there, Ngaldaddubbe im name now.

$$
\text { prop.n. }
$$

She was born there, and that's her name, Ngaldaddubbe.

17. BN: That Ngaldaddubbe now.

$$
\text { place/prop.n. }
$$

Ngaldaddubbe, that's her now. But nevertheless, I'll say her name

18. BN: But no matter, I call im my Ngaldaddubbe.

$$
\text { place.n. }
$$

I will call her name, my Ngaldaddubbe regardless. 
Indigenous and Minority Placenames

19. BN: / call him sister. I can't call him, might be.

I'll call the name of [my] sister. I'm not really supposed to say her name.

20. BN: Ka-warre. Bad ka-mak, bonj djang.

3-bad but 3-good finish sacred.site

It's not good. But it's OK because we're talking about the sacred site.

21. BN: Imin dai, ba-yakminj ba-rrowe-ng.

[KRIOL code mixing]

3P-finishPP 3P-die-PP

She died, she's finished.

22. BN: That Ngaldaddubbe.

That Ngaldaddubbe.

Bardayal draws on a mental map of the 'honey dreaming' region and commences with the camping place Kulnguki. From Kulnguki, 'upstream there' kaddum kunukka (line 1) is the sacred site for rock honey Ngaldaddubbe which is also the name of Bardayal's classificatory sister. Initially he does not mention her name (and the place) because of the taboo, but refers to her by a nearby placename Warnkulembakmeng (line 3) which acts as a referential substitute for the purposes of this conversation. In this case, a placename which cannot be uttered is replaced by a neighbouring name. This is not a random solution as Warnkulembakmeng is also a significant site in the Ankung Djang 'honey dreaming' complex. The name is bimorphemic warnkulem-bakmeng 'warnkulem (?)- broken' and may also be associated with the broken or amputated legs of the female honey spirit being Wakkewakken. In lines 11 and 16-18 Bardayal says the name of the place and therefore his sister, but he is clearly not at ease with such reference and he excuses himeself by calling the place bolk-balmarded, where bolk means 'place' and balmarded is an interjection that is most commonly used to express embarrassment when one hears a sibling subjected to joking relationship taunts and teasing, especially those of a sexual nature (see also Garde 2008b; Evans 1992). In this case, bolk-balmarded indexes a placename that encodes a sibling relationship to the speaker and that uttering this placename causes the speaker social embarrassment.

Placenames can be considered 'bad' in other ways. Embarrassing literal meanings may also result in bolk-balmarded reference as in (16), or the designation ka-bolkngeywarre 'the place with a bad name (literally: it-place-name-bad)'. There is a place Kubarledjawoy - a crossing on the Liverpool River along the Gunbalanya to Maningrida road. The name of this place literally means 'at the steamy vagina' and in certain contexts (especially those involving interaction between affinal kin), mention of the place is avoided and it is sometimes therefore 
referred to as ka-bolkngeywarre 'the place with the bad name'. Placenames can even be changed for this reason. In the late 1990s, Bardayal Nadjamerrek changed the name of a place on his Ankung Djang 'Honey Dreaming' estate. The place originally had two names:

Wak Kabanikebngurlminarren

Wak kabani-keb-ngurlmi-na-rren

crow 3ua-nose/face-dark-look-RR.NP

The two crows look at each other's black faces.

(22)

\author{
Wak Kakorddakan \\ wak ka-kord-da-kan \\ crow $3 \mathrm{~m}$-shit-in.sun-take.NP \\ Crow carries shit into the sun.
}

On expansion, the two names encode cultural meanings relating to the actions of two mythical crows. In one story they stand looking at each other's dark faces and in the other they carry bags of shit and place them in the hot sun. Image 2 is a photograph of Bardayal and his depiction of the two crow placenames. On one side of the painting the crows carry a bag of shit into the sun and on the other side the two crows look at each other's faces.

Such placenames were considered ka-bolkngeywarre 'bad placenames'. From the mid-1990s Bardayal was involved in a 'return to country' project that established an outstation and a land management program on his country at Kabulwarnamyo. He was involved in many years of intergenerational transfer of knowledge with younger Bininj who were encouraged to leave the town of Gunbalanya and find work in land management projects on his country. Wak Kabanikebngurlminarren (aka Wak Kakorddakan) was a popular camping place during the early days of this land management project, yet Bardayal always had reservations about referring to this place by these names. He therefore changed the name to Kulnguki (see his comment in text 23) but never explained the significance or origin of the new name, which is semantically unclear. It did however make the place easier to pronounce due to the marked reduction of syllables. Despite the change, knowledge about the original names and the association with crows persists through art works, including the rock art image at the site (see Image 3). 


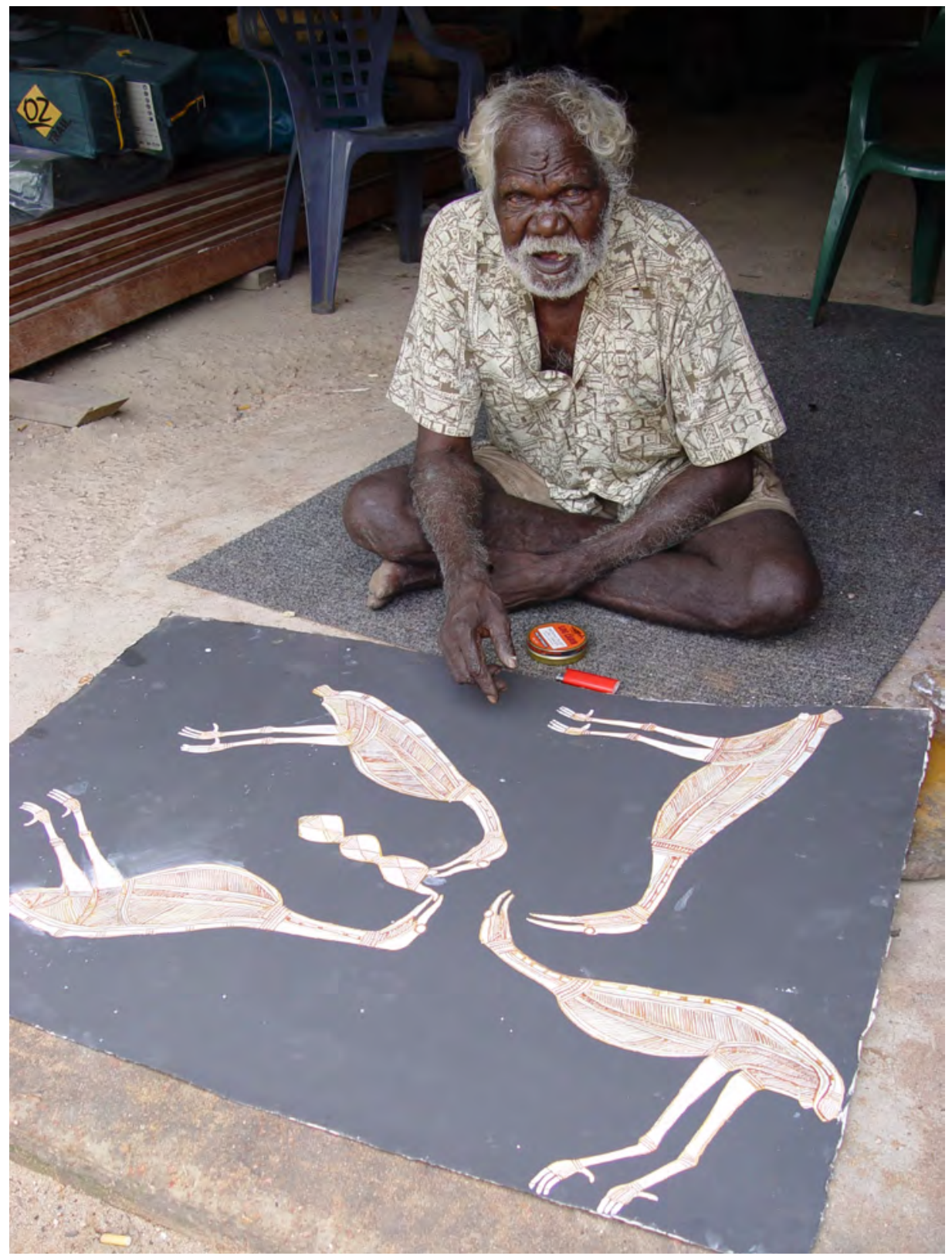

Image 2: Bardayal Nadjamerrek with this painting of "two crows carry shit into the sun' and the rock art image at Kulnguki of 'two crows looking at each other's dark faces'.

Source: Murray Garde. 


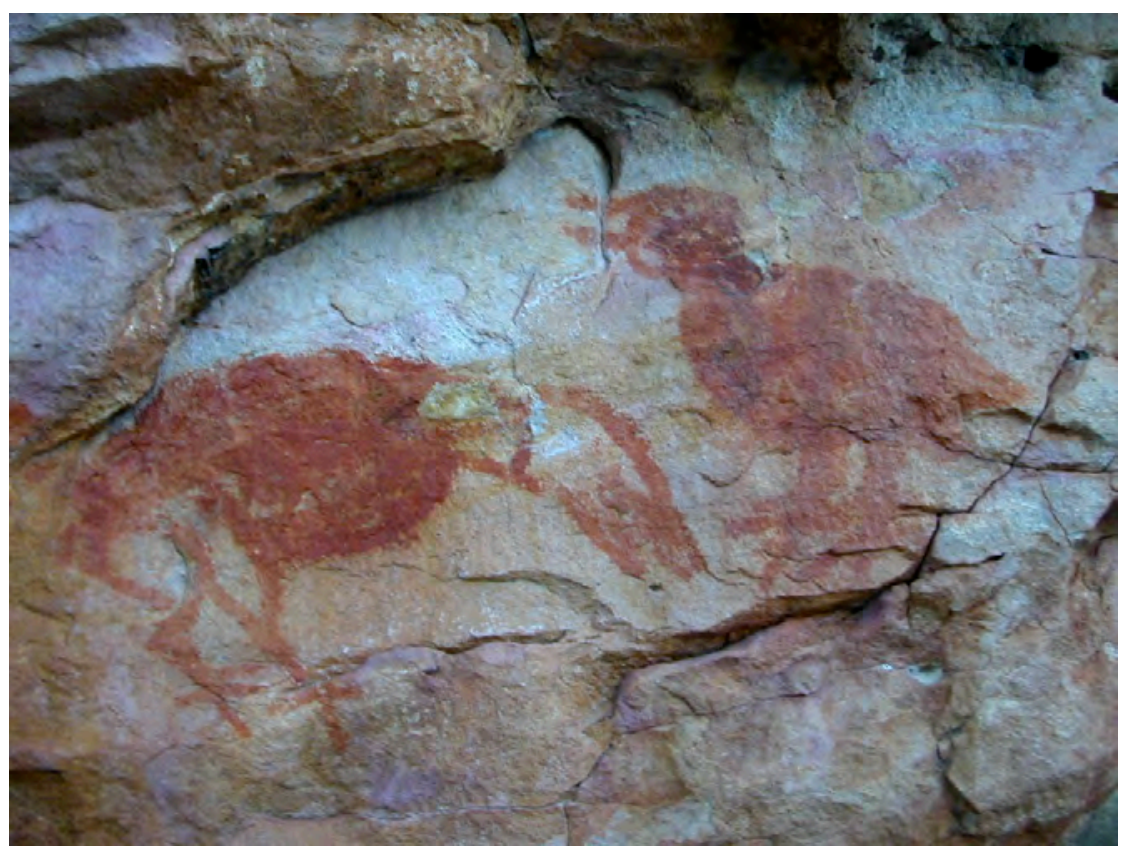

\section{Image 3: The rock art image of two crows looking at each other at the site Wak Kabanikebngurlminarren.}

Source: Murray Garde.

\section{Arringarrnghmangi Nawalbirn rorrbono, kabono- here Kulnguki Wak Kakorddakan. Ngayi ngadjendjihmeng Kulnguki.}

We used to walk along the open and flat country at Nawalbirn, along the creek here at Kulnguki or Wak Kakorddakan, but I changed it [the name] to Kulnguki.

Changing placenames due to shifts in sensibilities or for other pragmatic purposes is not uncommon in other languages. Numerous street names in medieval London would now be considered vulgar (by some perhaps) had they not been bowdlerised. For example, Sherborne Lane was changed from the former Shiteburn Lane, meaning 'shit house' - a reference to the numerous public lavatories in the street (Partridge 2004). The idea of inviting family and visitors to your camp at 'Crows carrying bags of shit' has likewise prompted a name change.

Placenames in Bininj Gunwok may also be used to refer to other objects. The exchange in (24) occurred some weeks after the incident referred to in (19) and again there is reference to the place Mankorlod. In this conversation, however, the placename is used to refer to a motor vehicle belonging to the same recently deceased person referred to in (19). 
Indigenous and Minority Placenames

\section{Q: Man-ngale ngurri-m-wam?}

III-who 2a-hith-goPP

Which one [man- class thing] did you come [in]?

\section{A: Man-djare $\quad$ ngarri-m-wam Mankorlod. \\ III-deceased.poss 1a-hith-goPP place.n.}

A deceased person's possession [of man- class] we came [in], [the one belonging to the person from] Mankorlod.

Motor vehicles are usually referred to either by a personal name of the owner or by some other characteristic such as the model and colour Greiwan Doyorra 'Grey one Toyota' or Clark nuye Djudjukki 'Clark's Suzuki'. The placename Mankorlod in (24) is a departure from this usual convention and so will be interpreted as a marked referring expression. The term man-djare means 'possessions of a deceased person' where the man- prefix on the interrogative suggests agreement with the class into which motor vehicles also fall. ${ }^{8}$ This provides a contextualisation cue (Gumperz 1982) to the interpretation of the placename that follows - 'a man- class possession of a deceased person from place $\mathrm{x}^{\prime}$. The association of the recent death and the place of this person's residence facilitates unproblematic reference that respects local conventions of circumspection when referring to the recently deceased.

\section{Placenames and joking}

Placenames are also used in Bininj Gunwok as part of both formal joking relationship interaction (Garde 2008b) but also more incidental good-natured joking especially between youths who share a high degree of social familiarity. The usual strategy is to disparage a key site in the joking partner's clan estate. The partner may then retaliate with a similar jibe about a key site in the country of his adversary. The exchange in (25) is typical of this type of joking.

$$
\begin{aligned}
& \text { A Bulkay ka-bolk-banj } \\
& \text { prop.n 3m-place-smell.bad } \\
& \text { Bulkay is a place that stinks. } \\
& \text { Ku-wid, kun-bolk-mak ku-mekke! } \\
& \text { LOC-another IV-place-good LOC-DEM } \\
& \text { Not at that place, that is a good place. }
\end{aligned}
$$

\footnotetext{
8 Motor vehicles are classed in the man-vegetal class on the basis of the semantic extention of wooden things > canoes $>$ vehicles of transport.
} 
A similar exchange between two young men who are not in kinship-mediated joking relationship, but who frequently joke with each other based on their close social familiarity, is that in (26).

\begin{tabular}{|c|c|c|c|}
\hline \multirow[t]{13}{*}{$(26)$} & \multirow[t]{3}{*}{1} & \multirow[t]{3}{*}{ A } & Na-kkan ngalkordo ka-m-h-re! \\
\hline & & & I-DEM brolga \\
\hline & & & Here comes brolga! \\
\hline & \multirow[t]{3}{*}{2} & \multirow[t]{3}{*}{ B } & Kandji wanjh na-kang Mankorlod! \\
\hline & & & jabiru SEQ I-from.place place.n \\
\hline & & & It's the jabiru from Mankorlod! \\
\hline & \multirow[t]{3}{*}{3} & \multirow[t]{3}{*}{ A } & Ku-wid, $\quad$ ngalkordo kure Kubumi ka-ngukde-ng \\
\hline & & & LOC-wrong.one brolga LOC place.n. 3-shits-NP \\
\hline & & & No, not that place, it's brolga from Kubumi which shits \\
\hline & \multirow[t]{3}{*}{4} & \multirow[t]{3}{*}{ A } & ku-bolk-kord-wern $\quad$ ka-bolk-warre-won. \\
\hline & & & LOC-place-faeces-much 3-place-bad-give. \\
\hline & & & everywhere and makes a mess. \\
\hline & 5 & $\mathrm{~A} / \mathrm{B}$ & [laughter] \\
\hline
\end{tabular}

Speaker A is a Kardbam clansman whose kun-bolkngeykimuk 'big placename' is Mankorlod (Cadell River tributary), whilst his joking partner is a Kulmarru clansman whose estate name or 'big place' is Kubumi (middle Mann River). The former is duwa moiety and the latter is yirridjdja. This is important because the two men use the names of birds associated with each other's moieties as part of the joke structure. Speaker A associates B with the brolga, a large duwa moiety bird whilst as a riposte, B lampoons the yirridjdja moiety Jabiru (or black-necked stork) 'from Mankorlod'. Again, reference to both people and and the places associated with them are frequently co-present and interchangeable, telling us something of the role of place in the conceptualisation of personhood.

\section{Conclusion}

Studies about placenames in Aboriginal Australia have typically grappled with systems and hierarchies of placename classification and their semantics how languages organise reference to place and how to explain the origins and meanings of placenames. I have in this chapter explored these same topics as a point of departure and then moved on to illustrate how placenames are used in interaction. In addition to geographical sites, placenames in Bininj Gunwok can refer to both people and things and are also used in conversation to achieve interactive goals. The recitation of placenames in the order they appear along Bininj man-bolh 'Aboriginal walking routes' reflects their significance as part of mental maps. These maps afford the user and listener various advantages such as how to get from A to B, how to validate knowledge and prove ownership of 
places, and how to establish the relationships amongst places. Whilst the vast majority of placenames in Western Arnhem Land are usually immutable in form and often semantically archaic, names do get changed or modified. Cultural conventions may at times require the avoidance of certain placenames, whilst in other less weighty contexts there is a place for the use of placenames in humour and light-hearted interaction. Toponyms in Bininj Gunwok are more than just designations for places, but that should come as no surprise in cultures where the conceptual boundaries between places, people and things are fluid.

\section{References}

Aklif, G. 1999, Ardiyooloon Bardi ngaanka: One Arm Point Bardi Dictionary, Kimberley Language Resource Centre, Halls Creek, Western Australia.

Bowern, C. 2009, 'Naming Bardi places', in Aboriginal Placenames: Naming and Renaming the Australian Landscape, Harold Koch and Luise Hercus (eds), Aboriginal History Monograph 19, ANU E Press and Aboriginal History Inc., Canberra: 327-346.

Enfield, N.J. 2009, 'Relationship thinking and human pragmatics', Journal of Pragmatics 41: 60-78.

Evans, N. 1992, “'Wanjh! Bonj! Nja !": Sequential organization and social deixis in Mayali interjections', Journal of Pragmatics 18: 225-244.

- 2003, Bininj Gun-wok: A Pan-dialectal Grammar of Mayali, Kunwinjku and Kune. (2 volumes), Pacific Linguistics, Canberra.

Garde, M. 2008a, 'Person reference, proper names and circumspection in Bininj Kunwok conversation', in Discourse and Grammar in Australian Languages, Brett Baker and Ilana Mushin (eds), John Benjamins, Amsterdam: 203-232.

— 2008b, 'The pragmatics of rude jokes with Grandad: Joking relationships in Aboriginal Australia', Anthropological Forum 18(3): 235-253.

— 2011, 'The Forbidden Gaze: The 1948 Wubarr ceremony performed for The American-Australian Scientific Expedition to Arnhem Land', in Exploring the Legacy of the 1948 Arnhem Land Expedition, Martin Thomas and M. Neale (eds), National Museum of Australia, Canberra: 403-422.

Gumperz, J. 1982, Discourse Strategies, Cambridge University Press, Cambridge.

Hercus, L., F. Hodges and J. Simpson (eds) 2002, The Land Is a Map: Placenames of Indigenous Origin in Australia, Pandanus Books in association with Pacific Linguistics, Canberra. 
Keen, I. 1994, Knowledge and Secrecy in an Aboriginal Religion, Oxford Studies in Social and Cultural Anthropology, Oxford University Press, Oxford.

Levinson, S. and N. Burenhult 2008, 'Language and landscape: a cross-linguistic perspective', Language Sciences 30: 135-150.

Merlan, F. 2001, 'Form and context in Jawoyn placenames', in Forty Years on: Ken Hale and Australian Languages, Jane Simpson, D. Nash, M. Laughren, P. Austin and B. Alpher (eds), Pacific Linguistics, Canberra: 367-384.

Morphy, H. 1984, Journey to the Crocodile's Nest: An Accompanying Monograph to the Film Madarrpa Funeral at Gurka'wuy, Australian Institute of Aboriginal Studies, Canberra.

Partridge, C. 2004, 'A street by any other name...', The Observer, http://www. guardian.co.uk/money/2004/apr/18/property.homebuyingl (accessed 20 March 2013).

Pierce, C. S. 1955, 'Logic as semiotic: the theory of signs', in Philosophical Writings of Peirce, Justus Buchler (ed.), Dover Publications, New York: 98-119.

Vries, L. de 2005, 'Towards a typology of tail-head linkage in Papuan languages', Studies in Language 29(2): 363-384. 
This text taken from Indigenous and Minority Placenames: Australian and International Perspectives, Edited by Ian D. Clark, Luise Hercus and Laura Kostanski, published 2014 by ANU Press, The Australian National University, Canberra, Australia. 